\title{
Poziom podstawowych cech budowy somatycznej oraz sprawności fizycznej młodych tancerek klasycznych, na tle rówieśniczek uprawiających akrobatykę sportową - charakterystyka porównawcza
}

\section{The level of fundamental qualities of somatic structure and phy- sical fitness of young classical dancers in comparison to their peers practising acrobatic gymnastics - a comparative analysis}

Classical (academic) dance, colloquially called ballet, is associated with subtlety and incredible grace of movement. Despite the fact that there has been ages from the creation of ballet, the undoubted beauty and airiness of the forms presented by the dancers make ballet still very popular throughout the world. Ballet is a kind of theatrical show with such fundamental elements as music, choreography and movement. Considering a ballet performance (obviously in a great simplification) and analysing it solely and exclusively within the aforementioned elements, it may be assumed that there is a parallel between the elements of classical dance and an acrobatic routine presented during competitions. Music, choreography and movement are essential in acrobatics as well.

The aim of this study is to compare the level of somatic qualities (body height and weight) and the characteristics of fundamental qualities of physical fitness (agility, strength, flexibility, liveliness) of ballet dancers, as well as presenting their results in comparison to dancers' peers practising acrobatic gymnastics.

The results of the analysis indicate that dancers are significantly taller than acrobats also when compared to the standards described in Drozdowski's „Dzieci Polski Zachodniej”. The adopted assumption of a lower level of general physical fitness of classical dancers in comparison to acrobats has been confirmed. At the same time, in an attempt to measure the flexibility of the body, a statistical difference has been observed within a group of 12-year old girls only. 


\section{Wprowadzenie}

Historia ewolucji człowieka jest ściśle związana z historią jego aktywności. Wszelkie aspekty ruchowej działalności człowieka występowały na każdym kroku jego rozwoju. Od prostych form aktywności podyktowanych naturalną potrzebą przetrwania do skomplikowanych we współczesnym sporcie. Jedną z najstarszych, a zarazem najprostszych form ekspresji ruchowej jest taniec. Towarzyszył on człowiekowi właściwie od początków jego istnienia. Akrobatykę sportową natomiast postrzega się jako stosunkowo młodą dyscyplinę sportu, choć ryciny świadczące o wykonywanych ćwiczeń akrobatycznych odnaleźć można na pochodzącym sprzed 2300 lat p.n.e. sarkofagu Beni Hassana, dowódcy wojsk egipskich (Polak, 2002). Prezentowane przez akrobatki układy cechują się dużą dynamiką, harmonią i widowiskowością, a pokazywane ćwiczenia charakteryzują się perfekcją, wykonywane są z uśmiechem i bez oznak zmęczenia. Natomiast taniec klasyczny (akademicki), potocznie zwany baletem, kojarzony jest z subtelnością oraz niebywałą gracją ruchu. Niewątpliwe piękno oraz lekkość prezentowanych przez tancerzy form sprawia, że od wieków balet cieszy się na całym świecie ogromną popularnością. Jest on pewnego rodzaju widowiskiem teatralnym, którego podstawowymi elementami są muzyka, choreografia oraz ruch. Rozpatrując spektakl baletowy (oczywiście w ogromnym uproszczeniu) i analizując go tylko i wyłącznie w zakresie wymienionych powyżej elementów, można przyjąć tezę, że występuje paralela pomiędzy elementami tańca klasycznego a prezentowanymi $w$ trakcie zawodów układami akrobatycznymi. Również w akrobatyce zasadniczą rolę odgrywają muzyka, choreografia oraz ruch. Na potwierdzenie postawionej tezy warto przytoczyć słowa Arndolda L. Haskell „Balet, jakim go znamy, narodził się w chwili, gdy akrobatyka zawodowca zjednoczyła się z gracją dworzanina" (Haskell, 1955).

Do kwestii tej nawiązuje Z. Drozdowski w Antropologii sportowej. Uważa on, że choć tańca nie zalicza się do dyscyplin sportowych, to jednak wiele ćwiczeń, które wykonują artyści, nie różni się w swej strukturze od tych wykonywanych choćby w gimnastyce artystycznej (Drozdowski, 1984).

Wszelkie działania w zakresie sportu kwalifikowanego skoncentrowane są na uzyskiwaniu jak najlepszego wyniku. Podobnie jest w treningu tancerzy. Niezależnie od poziomu sportowego zawodników czy też baletmistrzów, cel jest jeden: optymalne przygotowanie wszystkich cech niezbędnych do osiągnięcia mistrzostwa w swej dziedzinie.

Sport wyczynowy oraz taniec są szczególnymi przejawami ludzkiego działania, podczas którego organizm pracuje często w warunkach ekstremalnych. Nawet najcięższa praca zawodowa nie wywoła takich zmian adaptacyjnych w różnych układach organizmu, jakie występują u sportowców i tancerzy najwyższej klasy. Zjawisko to związane jest przede wszystkim z intensywnością pracy, która w warunkach treningów, zawodów oraz występów osiąga najwyższą wartość (Celka, 2007).

Wiemy dziś na podstawie badań, że osiągane sukcesy nie tylko sportowe są efektem długotrwałej adaptacji organizmu i składową wielu czynników, predyspozycji wrodzonych (morfologicznych, motorycznych, psychologicznych), wpływu środowiska zewnętrznego, pozasportowego oraz, oczywiście, treningu sportowego (Drozdowski, 1984). 


\section{Cel pracy, hipotezy}

Celem autorów niniejszej pracy jest porównanie poziomu podstawowych cech somatycznych (wysokości oraz masy ciała) oraz charakterystyka podstawowych cech sprawności fizycznej (zwinność, siła, gibkość, skoczność) tancerek baletowych, jak również przedstawienie uzyskanych przez nie wyników, na tle rówieśniczek trenujących akrobatykę sportową.

Wybór obu grup nie jest przypadkowy. Choć występują podobieństwa w strukturze prezentowanych elementów przez obie formy ruchu, to jednak należy oczekiwać wyraźnej przewagi w obszarze sprawności fizycznej dziewcząt trenujących akrobatykę sportową. Należy w tym miejscu nadmienić, że niniejsza praca jest fragmentem obszernych badań obejmujących - poza wymienionymi grupami - również dziewczęta trenujące pływanie synchroniczne oraz gimnastykę artystyczną. W kolejnych etapach realizowanych badań zestawione zostaną uzyskane rezultaty pozostałych grup.

\section{W pracy przyjęto trzy hipotezy:}

H1. Przyjmuje się, że dzieci w obu grupach badawczych charakteryzują się podobnym rozwojem fizycznym. Fakt wykonywania elementów tanecznych charakterystycznych dla baletu i ćwiczeń przygotowujących do uprawiania dyscyplin sportowych nie różnicuje obu grup. Badane grupy cechować się będą niższą od przeciętnej masą ciała.

H2. Zakłada się, że dziewczynki uczące się w szkole baletowej cechują się podobną gibkością tułowia, jak rówieśniczki trenujące akrobatykę sportową. Taki stan rzeczy związany jest ze zbliżoną strukturą niektórych ćwiczeń gimnastycznych wykonywanych przez obie grupy.

H3. Oczekuje się, że dziewczynki ćwiczące elementy charakterystyczne dla tańca klasycznego - baletu, cechują się mniejszą sprawnością fizyczną ogólną niż ich rówieśniczki trenujące akrobatykę sportową.

Na rozwój i poziom cech motorycznych bezpośrednio wpływają procesy dojrzewania i rośnięcia, natomiast indywidualny rozwój każdego dziecka uzależniony jest od wielu czynników środowiska, w jakim żyje, oraz czynników genetycznych. Największe różnice między młodymi ludźmi pojawiają się w okresie dojrzewania, ze względu na indywidualność tego procesu. Ma to odzwierciedlenie w rozwoju motorycznym, co oznacza, że wiek nie jest wyłącznym kryterium oceny rozwoju biologicznego danego dziecka, ale przybliża nam zmiany, które mogę zachodzić i zachodzą w młodym organizmie (Drozdowski, 1984).

Badaniom zostały poddane dziewczęta w wieku 11-13 lat, czyli na przełomie dwóch etapów rozwoju motorycznego człowieka: okresu wczesnoszkolnego oraz okresu pokwitania. 
Wiek 10-11 lat to końcowy etap okresu wczesnoszkolnego w rozwoju motorycznym. Charakteryzuje się on łatwością nauki nowych, a także złożonych koordynacyjnie ruchów. W literaturze określany jest jako "drugie apogeum w rozwoju motoryczności” lub „okres dziecka doskonałego”. Dzieci cechuje przede wszystkim harmonia proporcji ciała, zdolność skupienia uwagi na wykonywaniu danej czynności, a także zwiększone zainteresowanie wszechstronnym rozwojem motorycznym. Przemiany te korzystnie wpływają na zdolności koordynacyjne dziewcząt, które należy wykorzystać w treningu sportowym. Jest to idealny okres dla doskonalenia jakości ruchu, poczucia rytmu i panowania nad własnym ciałem, które to umiejętności niezbędne są do osiągnięcia przyszłego sukcesu. Etap ten trwa do momentu pojawienia się pierwszych wyraźnych oznak dojrzewania (Osiński, 2000).

W okresie pokwitania w całym organizmie zachodzą liczne przemiany, które wpływają na sferę motoryki. Zwiększa się wysokość, a następnie masa ciała. U dziewcząt zauważamy większą ilość nieaktywnej tkanki tłuszczowej. Zmieniają się także proporcje ciała, biodra ulegają dużemu poszerzeniu w stosunku do przyrostu barków, co szczególnie utrudnia dziewczętom wykonywanie ćwiczeń gimnastycznych. Znaczną różnicą jest fakt, że środek ciężkości ciała przesuwa się ku górze, co także ma wpływ na motorykę, np. podczas wykonywania ćwiczeń zwinnościowych. Jest to okres, w którym dużą rolę odgrywają hormony, wpływające między innymi na wzrost siły. Mięśnie ulegają rozrostowi, szczególnie gdy stymulowane są ćwiczeniami fizycznymi. Poziom koordynacji w okresie dojrzewania jest przedmiotem wielu sporów pomiędzy teoretykami. Istnieje pogląd, że tak wielkie zmiany w organizmie młodych osób miały zakłócać niektóre działania w zakresie motoryczności sportowej, jednak jest to sprawa bardzo indywidualna, nie dotyka wszystkich osób, a z pewnością nie w takim samym stopniu. Dla niektórych zdolności jest to ostatni etap rozwoju, a nawet ulegają one regresowi. Dla innych to najlepszy moment na znaczny postęp (Osiński, 2000).

\section{Materiał badawczy i metody badań}

Materiał empiryczny do pracy stanowią wyniki pomiarów przeprowadzonych na grupie ponad 80 dziewcząt w wieku 11-13 lat uprawiających taniec klasyczny oraz akrobatykę sportową. Grupa kontrolna stanowi zaledwie $25 \%$ wszystkich badanych, jednakże pomiary wykonano na wszystkich dziewczętach trenujących akrobatykę sportową w Szkole Mistrzostwa Sportowego w Poznaniu.

\section{Metody badań}

Rozwój fizyczny określono za pomocą pomiaru wysokości i masy ciała. Wysokość ciała wyznacza odległość między punktami vertex (V) i basis (B), czyli najwyższym punktem głowy ustawionej w płaszczyźnie frankfurckiej i podstawą, na 
której w pozycji wyprostowanej, z opuszczonymi wzdłuż tułowia kończynami górnymi, stoi badana osoba. Podczas pomiaru pięty pozostały złączone, a stopy lekko rozstawione. Odległość V-B zmierzono za pomocą antropometru. Do ustalenia masy ciała wykorzystano atestowaną wagę lekarską. Dziewczęta zostały zważone boso, w stroju gimnastycznym, przed wysiłkiem fizycznym (Drozdowski, 1998).

Sprawność fizyczną określano za pomocą Europejskiego Testu Sprawności Fizycznej „Eurofit”. (Grabowski, Szopa, 1991) Obejmuje on dziewięć prób. W przeprowadzonych badaniach wykorzystano cztery opisane poniżej, następnie porównano z wynikami uzyskanymi przez zawodniczki trenujące akrobatykę.

Zebrany materiał poddano opracowaniu statystycznemu, wyliczając podstawowe charakterystyki, minimalną, średnią arytmetyczną oraz błąd średniej, poziom istotności różnic pomiędzy obiema grupami, jak również odchylenie standardowe i błąd odchylenia standardowego (Arska-Kotlińska, Bartz, Wieliński, 2002).

\section{Analiza i wyniki badań}

Wysokość ciała

Poniższy obraz graficzny ilustruje wyniki pomiarów jednej z dwóch podstawowych cech somatycznych. Pierwszą poddaną analizie cechą była wysokość ciała. Badana grupa tancerek cechuje się większymi średnimi wartościami omawianego parametru we wszystkich porównywanych grupach. Jednakże różnice statystycznie istotne wystąpiły pomiędzy dziewczętami 13-letnimi i to w odniesieniu zarówno do akrobatek jak i do norm podanych przez Drozdowskiego.

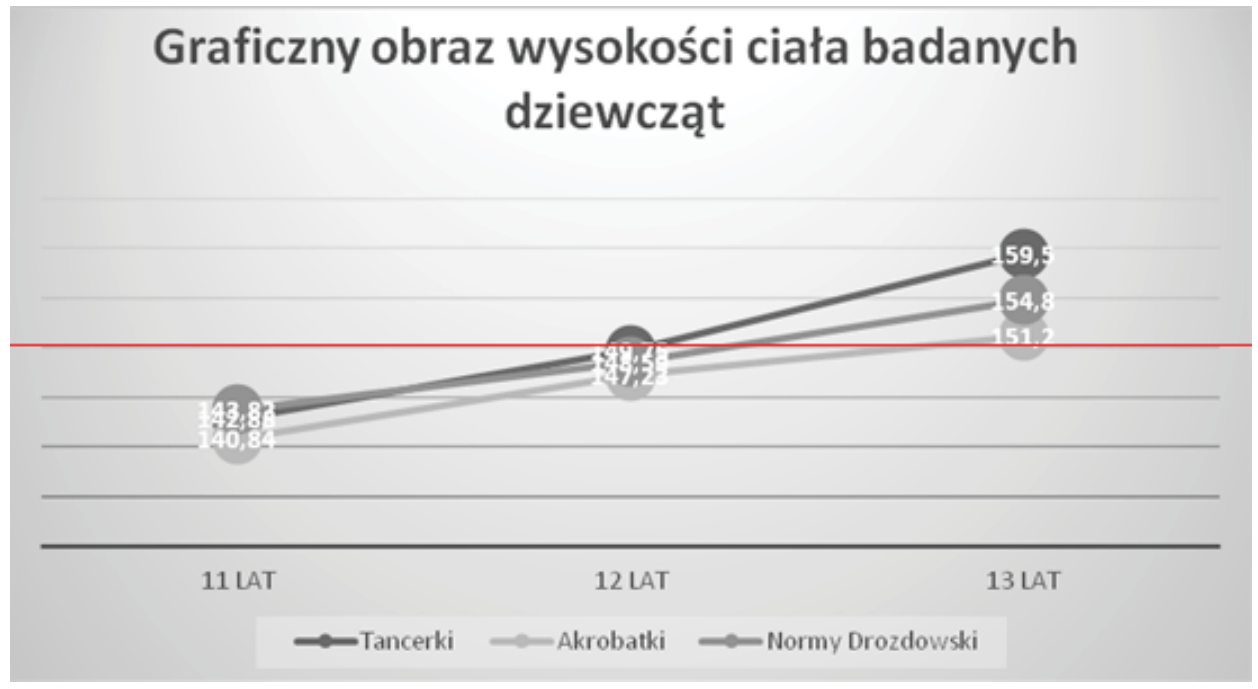

Rycina 1. Wyniki oraz porównanie średnich arytmetycznych pomiarów wysokości ciała

Źródło: badania własne. 
Tabela 1. Charakterystyka liczbowa średnich arytmetycznych wysokości ciała uczennic szkoły baletowej

\begin{tabular}{|l|c|c|c|c|}
\hline \multicolumn{1}{|c|}{ Wiek } & M & ס & Min & Max \\
\hline 11 lat & 142,88 & 7,06 & 131,00 & 156,50 \\
\hline 12 lat & 149,75 & 7,72 & 131,00 & 160,50 \\
\hline 13 lat & 159,50 & 5,42 & 147,00 & 169,00 \\
\hline
\end{tabular}

Źródło: badania własne.

Tabela 2. Charakterystyka liczbowa średnich arytmetycznych wysokości ciała uczennic Szkoły Mistrzostwa Sportowego o profilu akrobatyki

\begin{tabular}{|l|c|c|c|c|}
\hline \multicolumn{1}{|c|}{ Wiek } & M & $\delta$ & Min & Max \\
\hline 11 lat & 140,84 & 4,56 & 133,60 & 150,30 \\
\hline 12 lat & 147,23 & 7,33 & 141,20 & 157,20 \\
\hline 13 lat & 151,20 & 3,68 & 145,60 & 155,40 \\
\hline
\end{tabular}

Źródło: badania własne.

Tabela 3. Wyniki oraz porównanie średnich arytmetycznych pomiarów wysokości ciała

\begin{tabular}{|l|c|c|c|}
\hline \multicolumn{1}{|c|}{ Wiek } & Tancerki & Akrobatki & Normy wg Drozdowskiego \\
\hline 11 lat & 142,88 & 140,84 & 143,82 \\
\hline 12 lat & 149,75 & 147,23 & 148,59 \\
\hline 13 lat & 159,50 & 151,20 & 154,8 \\
\hline
\end{tabular}

Źródło: badania własne.

Jak wynika $z$ badań, których rezultaty prezentowane są w tabelach 1 i 2 , badana wysokość ciała dziewcząt w naturalny sposób zwiększa się w kolejnych grupach wiekowych. Najniższa przeciętna wysokość ciała występuje w grupie 11-letnich uczennic szkoły baletowej, gdzie $M=131 \mathrm{~cm}$, a najwyższa przeciętna w grupie 13-letnich dziewcząt uczących się tańca w szkole baletowej i wynosi $M=169 \mathrm{~cm}$. Z danych wynika, że średnie u dziewcząt ze Szkoły Mistrzostwa Sportowego zarówno u dziewcząt młodszych, jak i starszych są niższe niż dziewcząt ze szkoły baletowej.

Najniższa dziewczynka ze szkoły baletowej cechuje się wysokością ciała wynoszącą $131 \mathrm{~cm}$ i znajduje się w grupie 11-letnich dziewcząt. Najwyższa w tej grupie wiekowej mierzy $156,50 \mathrm{~cm}$. W grupie 12-letnich tancerek najniższa mierzy $131 \mathrm{~cm}$, a najwyższa $160,50 \mathrm{~cm}$. W grupie 13-letnich uczennic szkoły baletowej najniższa mierzy $147 \mathrm{~cm}$, natomiast najwyższa uczennica baletowa mierzy $169 \mathrm{~cm}$. Widoczny jest tutaj znacząca różnica pomiędzy 13-letnimi tancerkami baletowymi a ich młodszymi koleżankami. Odchylenie standardowe w grupach wiekowych wyniosło kolejno $+/-7,06,7,72,5,42$.

Minimalna wysokość ciała w grupie dziewcząt Szkoły Mistrzostwa Sportowego, w wieku 11 lat wynosi 133,60 cm, a najwyższa w tej grupie wiekowej mierzy $150,30 \mathrm{~cm}$. Najniższa uczennica w wieku 12 lat mierzy 141,20 cm, najwyższa zaś 
$157,20 \mathrm{~cm}$. W grupie wiekowej 13 lat najniższa uczennica ma $145,60 \mathrm{~cm}$, a najwyższa $155,40 \mathrm{~cm}$. W przypadku omawianych dziewcząt odchylenie standardowe badanej cechy wyniosło w następujących po sobie grupach: ${ }^{+} /-4,56,7,33,3,68$.

Masa ciała

Drugim parametrem somatycznym poddanym analizie była masa ciała. Odgrywa ona kluczową rolę w obu omawianych formach ruchu. Jej niski poziom często poprzez stosowanie wskaźnika wagowo-wzrostowego BMI, jest mylnie oceniany, jako niedowaga czy wręcz niedożywienie.

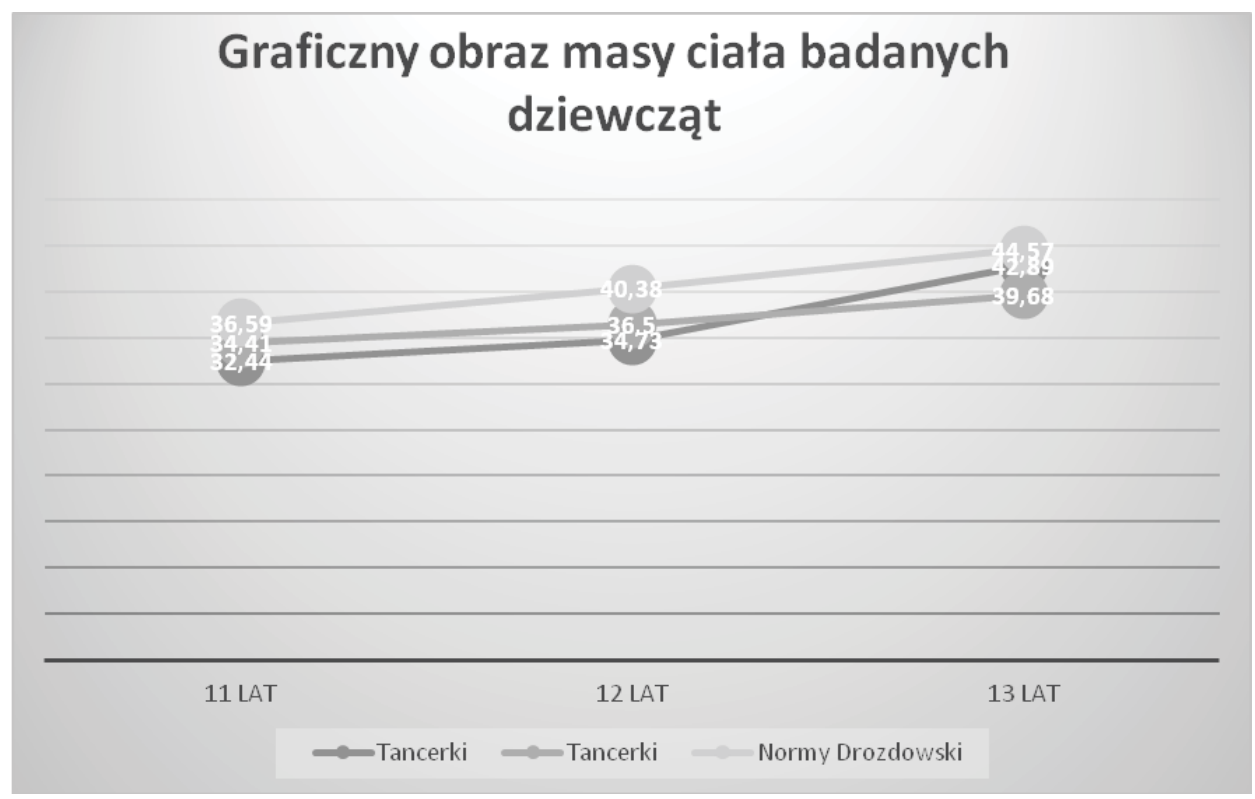

Rycina 2. Wyniki oraz porównanie średnich arytmetycznych masy ciała

Źródło: badania własne.

Rezultaty badań wyraźnie wskazują, że różnice statystycznie istotne wystąpiły grupach 11-i 12-letnich tancerek zestawiając je z normami. W obu przypadkach młode baletnice są wyraźnie lżejsze. Natomiast w najstarszej grupie nie zaobserwowano znaczących rozbieżności.

Kolejne tabele, 4 i 5, obrazują wyniki pomiarów masy ciała obu grup dziewcząt. Wyraźnie widać, że niska masa ciała badanych dziewczynek wzrasta wraz z wiekiem. Najniższa przeciętna masa ciała występuje u 11-letnich uczennic szkoły baletowej i wynosi $M=34,2 \mathrm{~kg}$. Najwyższa przeciętna masy ciała występuje również u uczennic trenujących taniec w grupie wiekowej 13 lat i wynosi 42,89 kg. Najmniejszą masą ciała charakteryzuje się dziewczynka trenująca taniec, waży ona zaledwie $24 \mathrm{~kg}$ i znajduje się w grupie 11 letnich dziewcząt, gdzie największa wartość tego parametru wynosi 41,20 kg. W grupie 12 letnich uczennic szkoły 
baletowej najniższa masa ciała osiąga $25,60 \mathrm{~kg}$, najwyższa $45,10 \mathrm{~kg}$. W grupie 13 letnich dziewcząt uprawiających balet najniższa masa ciała to $33,80 \mathrm{~kg}$, a największa 48,60 kg.

Minimalna wartość masy ciała w grupie wiekowej 11-letnich uczennic ze Szkoły Mistrzostwa Sportowego wynosi 26,60 kg, a maksymalna osiąga 44,10 kg. W grupie 12 letnich dziewczynek ze szkoły sportowej, najmniejsza wartość masy ciała wynosi $30,08 \mathrm{~kg}$, najwyższa 44,30. W przypadku 13-letnich uczennic z klasy akrobatycznej najmniejsza wartość masy ciała to $33,80 \mathrm{~kg}$, a najwyższa $48,60 \mathrm{~kg}$.

Porównując uzyskane wyniki (tabela 6), należy zauważyć, że badane dziewczęta ze szkoły baletowej charakteryzują się mniejszą masą ciała w grupie wiekowej 11 i 12 lat. Sytuacja ta zmienia się w chwili ukończenia 12 roku życia, kiedy masa ciała uczennic Ogólnokształcącej Szkoły Baletowej dość znacznie się zwiększa i uzyskuje przewagę nad masą ciała ich rówieśnic trenującymi akrobatykę sportową. Warto zwrócić uwagę, że wzrasta wówczas również wysokość ciała dziewczynek uprawiających taniec, uzyskując wartości wyższe niż charakteryzujące dziewczynki z klasy o profilu akrobatycznym.

Tabela 4. Charakterystyka liczbowa średnich arytmetycznych masy ciała uczennic szkoły baletowej

\begin{tabular}{|l|c|c|c|c|}
\hline \multicolumn{1}{|c|}{ Wiek } & M & ס & Min & Max \\
\hline 11 lat & 32,44 & 4,61 & 24,00 & 41,20 \\
\hline 12 lat & 34,73 & 5,31 & 25,60 & 45,10 \\
\hline 13 lat & 42,89 & 4,65 & 34,20 & 48,60 \\
\hline
\end{tabular}

Źródło: badania własne.

Tabela 5. Charakterystyka liczbowa średnich arytmetycznych masy ciała uczennic ze Szkoły Mistrzostwa Sportowego

\begin{tabular}{|l|c|c|c|c|}
\hline \multicolumn{1}{|c|}{ Wiek } & M & ठ & Min & Max \\
\hline 11 lat & 34,41 & 5,69 & 26,70 & 44,10 \\
\hline 12 lat & 36,50 & 5,67 & 30,08 & 44,30 \\
\hline 13 lat & 39,98 & 5,62 & 33,80 & 48,60 \\
\hline
\end{tabular}

Źródło: badania własne.

Tabela 6. Wyniki oraz porównanie średnich arytmetycznych masy ciała

\begin{tabular}{|l|c|c|c|}
\hline \multicolumn{1}{|c|}{ Wiek } & Tancerki & Akrobatki & Normy wg Drozdowskiego \\
\hline 11 lat & 32,44 & 34,41 & 36,59 \\
\hline 12 lat & 34,73 & 36,50 & 40,38 \\
\hline 13 lat & 42,89 & 39,68 & 44,57 \\
\hline
\end{tabular}

Źródło: badania własne.

\section{Ocena sprawności fizycznej}

Wysoki poziom gibkości, zwłaszcza tułowia, jest czynnikiem, który w znaczny sposób wpływa na poprawność i łatwość wykonywania trudnych elementów 
technicznych zarówno w tańcu, jak i w akrobatyce sportowej. Poniższa rycina 3 obrazuje wyniki badań przeprowadzonych w oparciu o próbę mierzącą gibkość poprzez wykonanie skłonu tułowia w przód w siadzie prostym.

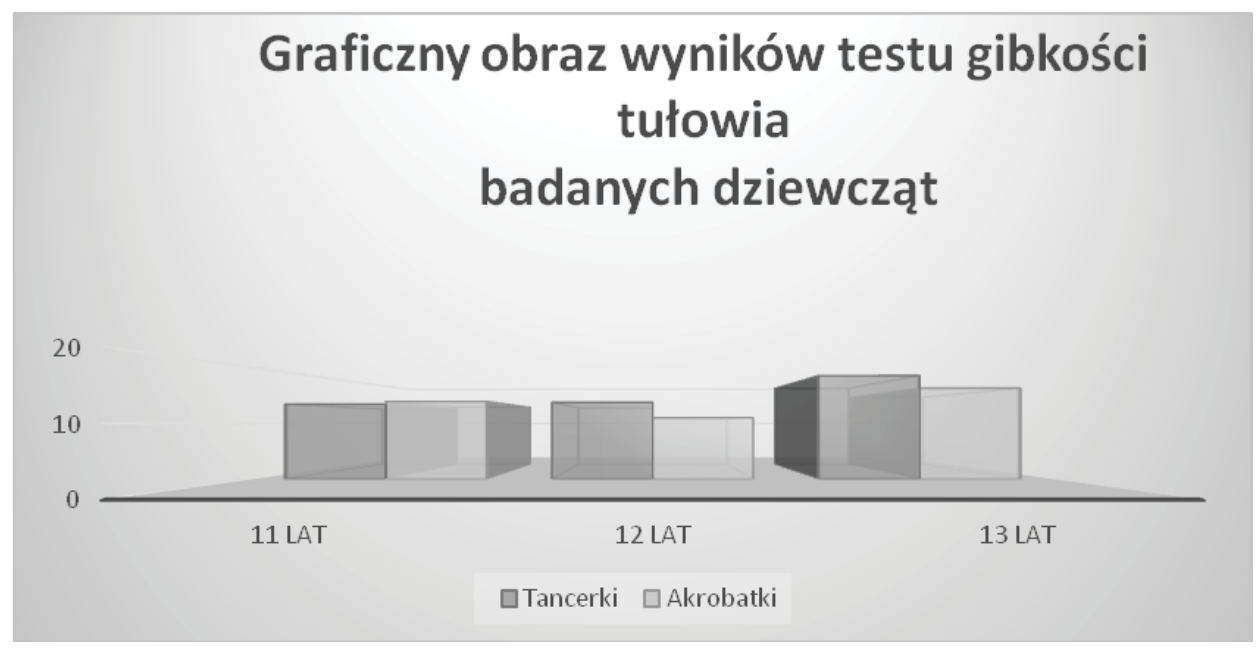

Rycina 3. Wyniki oraz porównanie średnich arytmetycznych pomiaru gibkości

Źródło: badania własne.

Wyniki badań przedstawione na rycinie 3 i tabelach 7, 8 wskazują, że dziewczynki ze szkoły baletowej z grupy wiekowej 13 lat cechują się największą gibkością gdzie $M=18,55 \mathrm{~cm}$. Wartość odchylenia standardowego $w$ kolejnych grupach wyniosła 5,20, 5,79, 4,59. Najmniejszą gibkością charakteryzują się uczennice Szkoły Mistrzostwa Sportowego z grupy wiekowej 12 lat, gdzie $M=11 \mathrm{~cm}$. Najlepszy wynik uzyskała uczennica Ogólnokształcącej Szkoły Baletowej, max $=26$, $5 \mathrm{~cm}, \mathrm{z}$ grupy wiekowej 13 lat, najgorszy natomiast uczennica tej samej szkoły $z$ grupy wiekowej 11 lat, $\min =1 \mathrm{~cm}$. W przypadku uczennic ze szkoły sportowej najlepszy wynik uzyskała dziewczynka przy $\max =22 \mathrm{~cm}$, a najgorszy $\min =4 \mathrm{~cm}$. Odchylenie standardowe wyniosło +/-4,5, 2,45, 5,32

Porównując uzyskane wyniki (tabela 9), należy stwierdzić, że w grupie wiekowej 11 lat przewagę uzyskały dziewczynki trenujące akrobatykę, lecz w kolejnych grupach wiekowych sytuacja ta zmienia się i lepsze wyniki uzyskują dziewczynki uprawiające taniec klasyczny. Jest to spowodowane tym, że w chwili rozpoczęcia nauki w szkole baletowej poziom gibkości nie jest jeszcze dostatecznie wysoki. Z każdym kolejnym rokiem treningów poprzez stosowanie specjalistycznych ćwiczeń, wartość tej cechy przyrasta u większości tancerek. Odchylenie standardowe badanej cechy wśród akrobatek wyniosło ${ }^{+} / 5,20,5,79$ oraz 4,59 dla najstarszej grupy dziewcząt. 
Tabela 7. Charakterystyka liczbowa średnich arytmetycznych gibkości uczennic szkoły baletowej

\begin{tabular}{|l|c|c|c|c|}
\hline \multicolumn{1}{|c|}{ Wiek } & $\mathbf{M}$ & $\boldsymbol{\delta}$ & Min & Max \\
\hline 11 lat & 13,44 & 5,20 & 1,0 & 20,5 \\
\hline 12 lat & 13,75 & 5,79 & 4,0 & 24,5 \\
\hline 13 lat & 18,55 & 4,59 & 10,0 & 26,5 \\
\hline
\end{tabular}

Źródło: badania własne.

Tabela 8. Charakterystyka liczbowa średnich arytmetycznych gibkości uczennic Szkoły Mistrzostwa Sportowego

\begin{tabular}{|l|c|c|c|c|}
\hline \multicolumn{1}{|c|}{ Wiek } & M & ठ & Min & Max \\
\hline 11 lat & 13,93 & 4,5 & 4 & 21 \\
\hline 12 lat & 11,00 & 2,45 & 8 & 13 \\
\hline 13 lat & 16,33 & 5,32 & 8 & 22 \\
\hline
\end{tabular}

Źródło: badania własne.

Tabela 9. Wyniki oraz porównanie średnich arytmetycznych pomiaru gibkości

\begin{tabular}{|l|c|c|}
\hline \multicolumn{1}{|c|}{ Wiek } & Tancerki & Akrobatki \\
\hline 11 lat & 13,44 & 13,93 \\
\hline 12 lat & 13,75 & 11 \\
\hline 13 lat & 18,55 & 16,33 \\
\hline
\end{tabular}

Źródło: badania własne

Odpowiednio wysoki poziom siły mięśni tułowia warunkuje utrzymanie prawidłowej postawy ciała. W przypadku dyscyplin sportu gimnastycznego, zwłaszcza gimnastyki sportowej czy akrobatyki, znaczna siła tych mięśni wpływa korzystnie nie tylko na możliwości techniczne wykonywanych elementów, ale także na bezpieczeństwo w trakcie ich wykonywania. $U$ tancerek klasycznych należy umiejętnie kształtować poziom tej cechy, nie jest ona jednak głównym determinantem powodzenia w trakcie wykonywania ćwiczeń baletowych.

Cechą, która w znaczący sposób różnicuje obie grupy jest właśnie siła mięśni tułowia. Wyniki badań zaprezentowane na rycinie 4 oraz w tabelach 10 i 11 wskazują, że znacząco lepsze wyniki uzyskały uczennice Szkoły Mistrzostwa Sportowego. Najlepszy wynik uzyskała dziewczynka z grupy wiekowej 13 lat, wykonując 34 poprawne skłony, natomiast najsłabszy wynik miała uczennica szkoły baletowej z grupy wiekowej 11 lat wykonując poprawnie jedynie siedem skłonów. Najmłodsze badane uczennice szkoły baletowej uzyskały średni wynik pomiaru siły mięśni tułowia $M=14,33$. W tej grupie wiekowej najmniejszą liczbę skłonów tułowia w przód uzyskała dziewczynka, która wykonała ich siedem, a maksymalny wynik to 19. Wśród 12 letnich dziewczynek minimalna odnotowana liczba skłonów to osiem, natomiast maksymalna 30. Średni wynik w tej grupie wiekowej wyniósł $M=18,56$. Wśród dziewczynek, które ukończyły 13 rok życia, średni wynik próby wyniósł $M=17,05$. W tej grupie wiekowej minimalny wynik to 11 skłonów, a maksymalny 23 . Odchylenie standardowe kształtowało się na poziomie 
+/-3,29, 5,01, 3,19. Dziewczynki ze Szkoły Mistrzostwa Sportowego w wieku lat 11 uzyskały średni wynik na poziomie $M=29$. Minimalna liczba poprawnie wykonanych skłonów w tej grupie wyniosła 23, a maksymalna 27 . O rok starsze dziewczynki trenujące akrobatykę sportową uzyskały średni wynik skłonów $M=28,25$. Jedna z tych dziewczynek uzyskała minimalną liczbę skłonów 26, a inna maksymalną 30. W grupie dziewczynek 13-letnich z tej samej szkoły średni wynik testu wyniósł $M=32,67$, najlepszy wynik to 34 skłony, zaś najgorszy -32 . Wartość odchylenia standardowego w kolejnych latach wyniosła +/-3,95, 1,71, 1,03.

Analiza danych porównawczych (tabela 11) oraz wyników przeprowadzonych badań w szkole baletowej wskazuje, że siła mięśni tułowia u dziewczynek trenujących akrobatykę sportową jest we wszystkich grupach wiekowych większa niż u uczennic baletu. Te wyniki pokazują po raz kolejny, że trening sportowy realizowany od 9 roku życia dał takie efekty. Interpretacja wyników osiągniętych przez uczennice szkoły baletowej wskazuje, że ćwiczenia związane z nauką tańca nie wymagają aż tak dużej siły mięśni tułowia, w przeciwieństwie do zajęć z akrobatyki sportowej.

\section{Graficzny obraz wyników testu siły mm tułowia badanych dziewcząt}

40

30

20

10

0

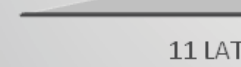

11 LAT

12 LAT

13 LAT

$\square$ Tancerki $\square$ Akrobatki

Rycina 4. Wyniki oraz porównanie średnich arytmetycznych pomiaru siły mięśni tułowia

Źródło: badania własne.

Tabela 10. Charakterystyka liczbowa średnich arytmetycznych siły mięśni tułowia uczennic szkoły baletowej

\begin{tabular}{|l|c|c|c|c|}
\hline \multicolumn{1}{|c|}{ Wiek } & M & ס & Min & Max \\
\hline 11 lat & 14,33 & 3,29 & 7 & 19 \\
\hline 12 lat & 18,56 & 5,01 & 8 & 30 \\
\hline 13 lat & 17,05 & 3,19 & 11 & 23 \\
\hline
\end{tabular}

Źródło: badania własne. 
Tabela 11. Charakterystyka liczbowa średnich arytmetycznych siły mięśni tułowia uczennic Szkoły Mistrzostwa Sportowego

\begin{tabular}{|l|c|c|c|c|}
\hline \multicolumn{1}{|c|}{ Wiek } & M & $\boldsymbol{\delta}$ & Min & Max \\
\hline 11 lat & 29,00 & 3,95 & 23 & 27 \\
\hline 12 lat & 28,25 & 1,71 & 26 & 30 \\
\hline 13 lat & 32,67 & 1,03 & 32 & 34 \\
\hline
\end{tabular}

Źródło: badania własne.

Tabela 12. Wyniki oraz porównanie średnich arytmetycznych pomiaru siły mięśni tułowia

\begin{tabular}{|l|c|c|}
\hline \multicolumn{1}{|c|}{ Wiek } & Tancerki & Akrobatki \\
\hline 11 lat & 14,33 & 29,00 \\
\hline 12 lat & 18,56 & 28 \\
\hline 13 lat & 17,05 & 32,67 \\
\hline
\end{tabular}

Źródło: badania własne.

Z punktu widzenia wykonywanych elementów choreograficznych zasadne wydawało się sprawdzenie poziomu skoczności obu grup. Choć struktura ruchu w akrobatyce skłania do wykonywania tzw. skoków tempowych, cechujących się dużą dynamiką, to jednak i w tańcu klasycznym występują elementy skoków czy piruetów.

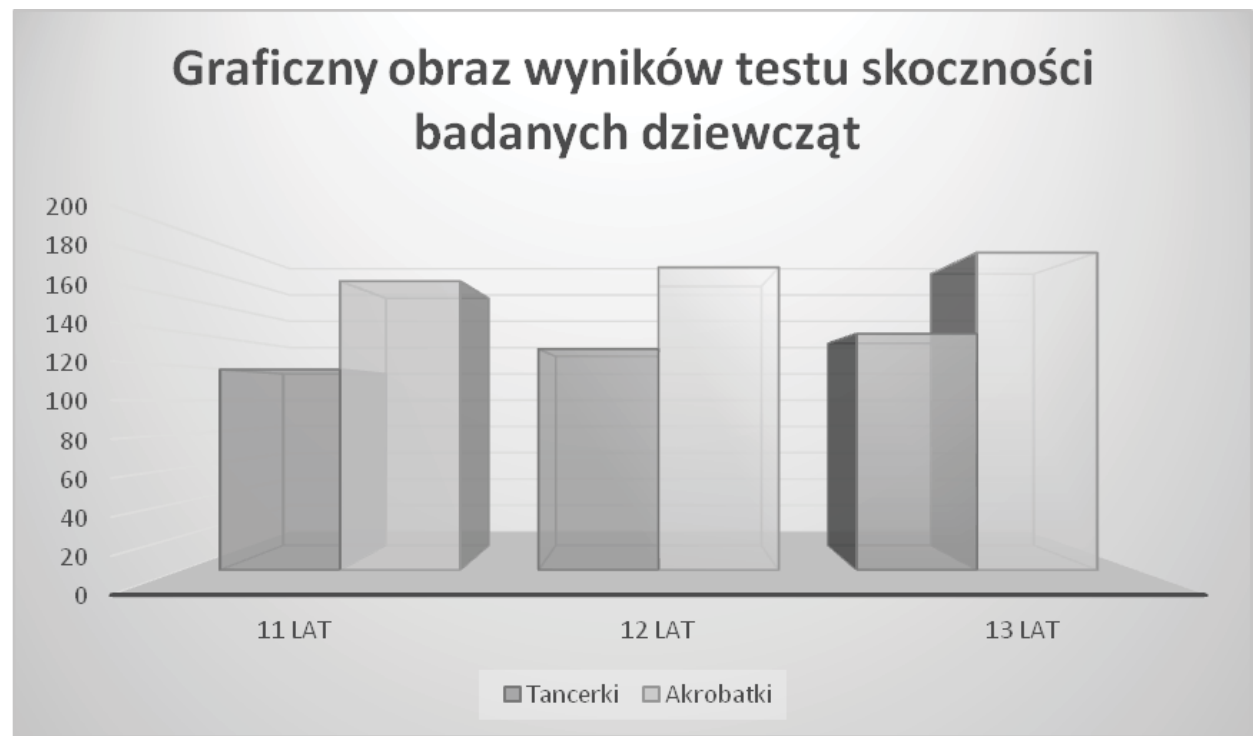

Rycina 5. Wyniki oraz porównanie średnich arytmetycznych pomiaru skoczności

Źródło: badania własne. 
Wyniki przeprowadzonych badań zobrazowanych w tabelach 13-15 oraz na rycinie 5 wskazują, że dziewczynki ze Szkoły Mistrzostwa Sportowego cechują się znacznie większą skocznością, a najlepszy wynik uzyskała uczennica trenująca akrobatykę $\max =210 \mathrm{~cm}$ w grupie wiekowej 13 lat, zaś najgorszy $\mathrm{w}$ tej grupie wynosi $\min =170 \mathrm{~cm}$. Uczennice ze szkoły baletowej uzyskały zdecydowanie gorsze wyniki przy $\max =176 \mathrm{~cm}$, a $\min =81 \mathrm{~cm}$. Średnie arytmetyczne wyliczone w badanych grupach znacząco się różnią. Średnia w grupie wiekowej 11 lat w przypadku dziewczynek ze szkoły baletowej wynosi $M=118 \mathrm{~cm}$, gdzie ich rówieśniczki ze szkoły sportowej uzyskały $M=169,93 \mathrm{~cm}$. W grupie 12-letnich dziewczynek trenujących taniec średnia wynosi $M=130 \mathrm{~cm}$, a u trenujących akrobatykę $\mathrm{M}=178 \mathrm{~cm}$. W ostatniej badanej grupie wiekowej 13-letnich uczennic szkoły baletowej średnia wynosi $\mathrm{M}=139 \mathrm{~cm}$, a u ich rówieśniczek ze szkoły sportowej $\mathrm{M}=186,67 \mathrm{~cm}$. Odchylenie standardowe $\mathrm{w}$ grupie tancerek wyniosło $+/-18,20,18$ natomiast odpowiednio w badanej grupie akrobatek $+/-12,7,10,10$ oraz 13,1 .

Tabela 13. Charakterystyka liczbowa średnich arytmetycznych skoczności uczennic szkoły baletowej

\begin{tabular}{|l|c|c|c|c|}
\hline \multicolumn{1}{|c|}{ Wiek } & M & ס & Min & Max \\
\hline 11 lat & 118 & 18 & 81 & 156 \\
\hline 12 lat & 130 & 20 & 100 & 161 \\
\hline 13 lat & 139 & 18 & 96 & 176 \\
\hline
\end{tabular}

Źródło: badania własne.

Tabela 14. Charakterystyka liczbowa średnich arytmetycznych skoczności uczennic Szkoły Mistrzostwa Sportowego

\begin{tabular}{|l|c|c|c|c|}
\hline \multicolumn{1}{|c|}{ Wiek } & $\mathbf{M}$ & $\mathbf{\delta}$ & Min & Max \\
\hline 11 lat & 169,93 & 12,8 & 142 & 192 \\
\hline 12 lat & 178,00 & 10,10 & 170 & 191 \\
\hline 13 lat & 186,67 & 13,31 & 170 & 210 \\
\hline
\end{tabular}

Źródło: badania własne.

Tabela 15. Wyniki oraz porównanie średnich arytmetycznych pomiaru skoczności

\begin{tabular}{|l|c|c|}
\hline \multicolumn{1}{|c|}{ Wiek } & Tancerki & Akrobatki \\
\hline 11 lat & 118 & 169,93 \\
\hline 12 lat & 130 & 178 \\
\hline 13 lat & 139 & 186,67 \\
\hline
\end{tabular}

Źródło: badania własne.

Zwinność rozumiana, jako umiejętność dokładnego oraz szybkiego wykonywania zmian kierunku ruchu całego ciała, bądź też jego części w trakcie 
wykonywania różnych czynności ruchowych (Barański, 1969), z całą pewnością należy do cech, które w znaczący sposób będą wpływały na poprawność i dokładność wykonywania technicznych elementów akrobatycznych, ale również i tanecznych.

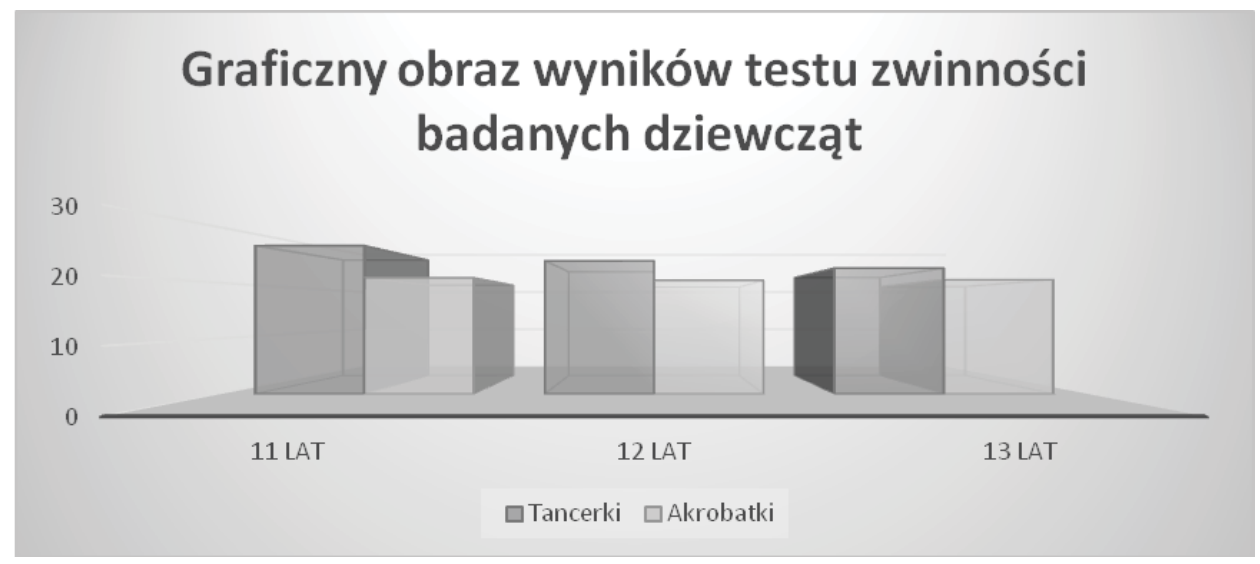

Rycina 6. Wyniki oraz porównanie średnich arytmetycznych pomiaru zwinności

Źródło: badania własne.

Zilustrowane na rycinie 6 i w tabelach 16 i 17 wyniki badań wskazują, że w grupie dziewczynek 11-letnich uczących się w szkole baletowej średni czas wykonania próby wyniósł $M=26,47 \mathrm{~s}$. Należy zaznaczyć, że najkrótszy czas wyniósł 23,76 s, a najdłuższy czas 30,68 s. Wśród dziewczynek 12-letnich, które uczęszczają na balet minimalny czas próby wyniósł $20,30 \mathrm{~s}$, a maksymalny $27,11 \mathrm{~s}$, co dało średni czas $M=23,96$. Dziewczynki 13-letnie podczas testu zwinności osiągnęły średni czas $M=22,63 \mathrm{~s}$. W tej grupie wiekowej minimalny czas próby wyniósł $23,01 \mathrm{~s}$, a maksymalny czas próby $25,10 \mathrm{~s}$. Odchylenie standardowe w poszczególnych grupach wiekowych wyniosło odpowiednio +/-1,59 dla 11-letnich tancerek i 2,00 oraz 1,65 dla starszych dziewcząt.

W porównywalnych grupach dzieci uczęszczające do Szkoły Mistrzostwa Sportowego osiągnęły następujące wyniki. W kategorii 11-latków minimalny czas próby wyniósł $19,28 \mathrm{~s}$, a maksymalny zmierzony czas wyniósł $25,31 \mathrm{~s}$. Średni czas w tej grupie wiekowej wyniósł $M=20,89$ s. Dziewczynki, które ukończyły 12 lat uzyskały średni wynik prowadzonego testu $M=20,44 \mathrm{~s}$. W tej grupie wiekowej dziewczynek uczących się w szkole sportowej minimalny wynik próby wyniósł 19,16 s, a maksymalny 29,22 s. Uczennice szkoły sportowej, które ukończyły 13 rok życia, uzyskały średni czas $M=20,55$ s. Należy nadmienić, że najniższy czas próby, jaki został zmierzony w tej grupie wiekowej, to $19,30 \mathrm{~s}$, a najdłuższy to $25,58 \mathrm{~s}$. Wśród badanych dziewczynek również wyliczono odchylenie standardowe i wyniosło ono kolejno ${ }^{+} / 1,48,0,91$ oraz 1,54.

Porównując dane uzyskane w przeprowadzonych testach w poszczególnych grupach wiekowych dzieci uczęszczających do Państwowej Szkoły Baletowej 
oraz dzieci uczących się w Szkole Mistrzostwa Sportowego (tabela 18), uzyskano rezultaty, z których wyraźnie wynika, że dziewczynki uczące się w szkole mistrzostwa sportowego w teście zwinności osiągnęły zdecydowanie krótsze czasy przeprowadzonego testu. Z analizy testów wynika również, że rezultaty osiągane przez uczennice szkoły baletowej wraz z wiekiem ulegają zdecydowanej poprawie. Wśród uczennic Szkoły Mistrzostwa Sportowego, mimo że czasy były zdecydowanie krótsze niż uczennic szkoły baletowej, to jednak różnice średnich czasów w poszczególnych grupach wiekowych były już nieznaczne.

Tabela 16. Charakterystyka liczbowa średnich arytmetycznych zwinności uczennic szkoły baletowej

\begin{tabular}{|l|c|c|c|c|}
\hline \multicolumn{1}{|c|}{ Wiek } & M & $\mathbf{\delta}$ & Min & Max \\
\hline 11 lat & 26,47 & 1,59 & 23,76 & 30,68 \\
\hline 12 lat & 23,96 & 2,00 & 20,30 & 27,11 \\
\hline 13 lat & 22,63 & 1,65 & 20,01 & 25,10 \\
\hline
\end{tabular}

Źródło: badania własne.

Tabela 17. Charakterystyka liczbowa średnich arytmetycznych zwinności uczennic Szkoły Mistrzostwa Sportowego

\begin{tabular}{|l|c|c|c|c|}
\hline \multicolumn{1}{|c|}{ Wiek } & M & $\mathbf{\delta}$ & Min & Max \\
\hline 11 lat & 20,89 & 1,48 & 19,28 & 25,31 \\
\hline 12 lat & 20,44 & 0,91 & 19,16 & 21,22 \\
\hline 13 lat & 20,55 & 1,54 & 19,30 & 25,58 \\
\hline
\end{tabular}

Źródło: badania własne.

Tabela 18. Wyniki oraz porównanie średnich arytmetycznych pomiaru zwinności

\begin{tabular}{|l|c|c|}
\hline Wiek & Tancerki & Akrobatki \\
\hline 11 lat & 26,67 & 20,89 \\
\hline 12 lat & 23,96 & 20,44 \\
\hline 13 lat & 22,63 & 20,55 \\
\hline
\end{tabular}

Źródło: badania własne.

\section{Podsumowanie}

Przedstawione doniesienie $z$ badań stanowi fragment większego opracowania obejmującego nie tylko pomiary cech somatycznych i sprawności fizycznej ogólnej, ale również ocenę równowagi przeprowadzonej na platformie balansowej. Przedstawione wyniki stanowią uzupełnienie tych badań. Celowo porównaniu poddane zostaną grupy dziewcząt uprawiających akrobatykę sportową, gimnastykę artystyczną, pływanie synchroniczne oraz balet.

Celem analizy było porównanie rozwoju fizycznego oraz sprawności fizycznej ogólnej dwóch grup dziewcząt uprawiających taniec klasyczny oraz akrobatykę 
sportową. Obie formy ruchu łączy udział muzyki w prezentowanych układach, a więc i choreografia. Choć w akrobatyce występują elementy taneczne, to daleko im jednak do harmonii ruchów baletowych.

Warto odnotować, że zarówno taniec jak i ćwiczenia akrobatyczne nie wpływają w żaden sposób negatywnie na rozwój fizyczny badanych dziewczynek. Wykazano bowiem, że masa ciała wszystkich grup wzrasta wraz z wiekiem. Zaobserwowano jednak, że masa ciała dziewczynek ze szkoły baletowej w wieku od 11 do 12 lat była nieznacznie niższa niż dziewcząt trenujących akrobatykę sportową. Między 12 a 13 rokiem życia proporcje te uległy zmianie. Dziewczynki ze szkoły baletowej w wieku 13 lat osiągnęły średnią masę ciała większą niż dziewczynki ze szkoły sportowej. Zarówno sport, jak i taniec wymaga stałego monitorowania masy ciała. Zawodniczki robią to właściwie podczas każdego treningu, natomiast tancerki obowiązkowe ważenie mają raz w miesiącu.

Biorąc pod uwagę analizę wyników wysokości ciała zgodnie z oczekiwaniami zaobserwowano stopniowy wzrost wysokości ciała w stosunku do wieku. Uczennice ze szkoły baletowej w najmłodszej grupie badawczej były wyższe od akrobatek i stan ten utrzymywał się aż do 13 roku życia. Wśród uczennic szkoły sportowej, których wysokość ciała ogólnie jest niższa niż uczennic szkoły baletowej, pomiędzy 12 a 13 rokiem życia przyrost wysokości ciała następował łagodniej. Reasumując, przyrost wysokości ciała w obu grupach uczennic równolegle następował pomiędzy 11 a 12 rokiem życia. Od 12 roku życia przyrost wysokości ciała baletnic odznacza się większą dynamiką niż u dziewczynek uprawiających akrobatykę sportową.

W odniesieniu do stanu sprawności fizycznej zauważono, że wyraźnie lepiej w kolejnych testach sprawdzających gibkość, skoczność, zwinność oraz siłę mięśni brzucha zaprezentowały się dziewczynki z grupy porównawczej, tzn. ze Szkoły Mistrzostwa Sportowego w Poznaniu. Zaobserwowano również, że dziewczynki uprawiające akrobatykę sportową poddane są podobnemu treningowi gibkościowemu, kształtującemu poszczególne partie ciała, podobnie jak ich rówieśniczki ze szkoły baletowej, lecz w dyscyplinie tej jednocześnie wymagana jest od nich większa siła fizyczna. Sprawia to, że podczas poszczególnych testów uczennice szkoły baletowej osiągnęły rezultaty gorsze. Wyniki te nie są niczym zaskakującym.

Należy w tym miejscu zaznaczyć, że dziewczynki uczące się w szkole baletowej rozpoczynają naukę w niej i zarazem ćwiczenia fizyczne ukierunkowane na taniec w wieku 11 lat. Natomiast dziewczynki uczące się w Szkole Mistrzostwa Sportowego i uczęszczające na zajęcia z akrobatyki sportowej ukierunkowany trening rozpoczynają w wieku lat 9. Oznacza to, że dziewczynki ze szkoły baletowej poddawane są intensywnym ćwiczeniom o 2 lata później niż ich rówieśniczki ze szkoły sportowej.

Z całą pewnością dziewczynki z Ogólnokształcącej Szkoły Baletowej uczestniczą w ćwiczeniach fizycznych organizowanych przez bardzo doświadczoną kadrę nauczycielską. Proces dydaktyczny w tej szkole opiera się na 60-letniej historii placówki oraz wieloletnim doświadczeniu profesjonalnych tancerzy, którzy po zakończeniu kariery artystycznej zajęli się nauką w tej szkole. Ich doświadczenie w zakresie rozwoju sprawności fizycznej uczennic szkoły baletowej oraz osiąganiu wysokiego poziomu artystycznego jest kluczowe. 


\section{Wnioski}

1. Zaobserwowano, że badane dziewczęta w wieku 11 i 12 lat cechują się podobną budową ciała w odniesieniu do parametru wysokości oraz masy ciała. Wyraźne różnice wystąpiły jedynie w grupie 13-latek. Tancerki charakteryzują się wyraźnie wyższą wysokością ciała aniżeli akrobatki oraz jak wskazują opracowane przez Drozdowskiego normy Dzieci Polski Zachodniej. Występujący trend potwierdzają wyniki badań Stańdy, wskazujące, że tancerki baletowe cechują się smukłą sylwetką i większymi wymiarami długościowymi kończyn górnych i dolnych oraz tułowia.

2. Wyniki przeprowadzonej analizy zebranego materiału badawczego potwierdziły przyjęte założenie o niższym poziomie sprawności fizycznej ogólnej tancerek klasycznych w stosunku do akrobatek. Jednocześnie w odniesieniu do próby mierzącej gibkość tułowia, różnicę statystyczną zaobserwowano jedynie w grupie 12-letnich dziewcząt.

3. Przy okazji badań zwrócono uwagę, że zajęcia ruchowe w szkole baletowej ograniczone są jedynie do ćwiczeń z zakresu różnorodnych form tanecznych. Należy przypuszczać, że niewiele spośród dziewcząt zwiąże swą przyszłość zawodową z tańcem klasycznym. Tym bardziej warto przyjrzeć się stosunkowo niskiemu poziomowi sprawności fizycznej ogólnej młodych, rozwijających się dziewcząt.

\section{Literatura}

Arska-Kotlińska M., Bartz J., Wieliński D., 2002, Wybrane zagadnienia statystyki dla studiujących wychowanie fizyczne, Wydawnictwo AWF w Poznaniu, Poznań.

Barański A., 1969, Próba klasyfikacji nominalnych definicji znamion motoryczności człowieka, „Wychowanie Fizyczne i Sport", t. 12, nr 3, s. 66-67.

Celka R., 2007, Morfologiczne i motoryczne czynniki determinujące wynik sportowy zawodników uprawiających skoki akrobatycznych na ścieżce, dysrtacja doktorska, AWF, Poznań.

Drozdowski Z., 1984, Antropologia sportowa, Wydawnictwo AWF w Poznaniu, Poznań, s. 73, 152.

Drozdowski Z., 998, Antropometria w wychowaniu fizycznym, Wydawnictwo AWF w Poznaniu, Poznań.

Grabowski H., Szopa J., 1991, Europejski Test Sprawności Fizycznej, Wydawnictwo Skryptowe, nr 103, Wydawnictwo AWF w Krakowie, Kraków.

Haskell A.L., 1955, Balet, Polskie Wydawnictwo Muzyczne, Warszawa, s. 22.

Osiński W., 1991, Zagadnienia motoryczności człowieka, Skrypty, nr 66, Wydawnictwo AWF w Poznaniu, Poznań.

Osiński W., 1994, Rozwój motoryczny człowieka w okresie ontogenezy, (w:) Motoryczność człowieka - jej struktura, zmienność i uwarunkowania, Monografie, nr 310, Wydawnictwo AWF w Poznaniu, Poznań, s. 39-61.

Osiński W., 2000, Antropomotoryka, Podręczniki, nr 49, Wydawnictwo AWF w Poznaniu, Poznań.

Polak E., 2003, Akrobatyka sportowa w Polsce, Wydawnictwo Uniwersytetu Rzeszowskiego, Rzeszów, s. 297.

Prus G., 2003, Trening sportowy. Antropomotoryka, Wydawnictwo AWF, Katowice, s. 187-192. 